\title{
Application of Deep, Vacuum, and Air Frying Methods to Fry Chub Mackerel (Scomber japonicus)
}

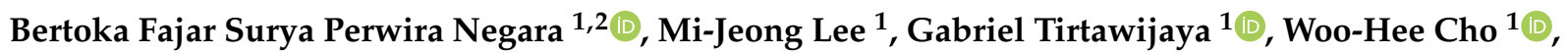 \\ Jae-Hak Sohn ${ }^{1,2}$, Jin-Soo Kim ${ }^{3, *}$ and Jae-Suk Choi ${ }^{1,2, *}$
}

1 Seafood Research Center, Industry-Academic Cooperation Foundation, Silla University, Advanced Seafood Processing Complex, 606 Wonyang-ro, Amnam-dong, Seo-gu, Busan 49277, Korea; ftrnd12@silla.ac.kr (B.F.S.P.N.); ftrnd10@silla.ac.kr (M.-J.L.); tirtawijayag@yahoo.com (G.T.); ftrnd3@silla.ac.kr (W.-H.C.); jhsohn@silla.ac.kr (J.-H.S.)

2 Department of Food Biotechnology, College of Medical and Life Sciences, Silla University, 140 Baegyang-daero 700 beon-gil, Sasang-gu, Busan 46958, Korea

3 Department of Seafood and Aquaculture Science, Gyeongsang National University, 38 Cheondaegukchi-gil, Gyeongsangnam-do, Tongyeong-si 53064, Korea

* Correspondence: jinsukim@gnu.ac.kr (J.-S.K.); jsc1008@silla.ac.kr (J.-S.C.); Tel.: +82-557-729-146 (J.-S.K.); +82-512-487-789 (J.-S.C.)

check for updates

Citation: Negara, B.F.S.P.; Lee, M.-J.; Tirtawijaya, G.; Cho, W.-H.; Sohn, J.-H.; Kim, J.-S.; Choi, J.-S. Application of Deep, Vacuum, and Air Frying Methods to Fry Chub Mackerel (Scomber japonicus). Processes 2021, 9, 1225. https:// doi.org/10.3390/pr9071225

Academic Editors: Dariusz Dziki and Anet Režek Jambrak

Received: 16 June 2021

Accepted: 14 July 2021

Published: 15 July 2021

Publisher's Note: MDPI stays neutral with regard to jurisdictional claims in published maps and institutional affiliations.

Copyright: (c) 2021 by the authors. Licensee MDPI, Basel, Switzerland. This article is an open access article distributed under the terms and conditions of the Creative Commons Attribution (CC BY) license (https:// creativecommons.org/licenses/by/ $4.0 /)$.

\begin{abstract}
Frying is an old method of processing food, especially fish. Mackerel is one of the most consumed fish worldwide because of its high nutritional value. Previously, only a study on the effects of deep frying of fried mackerel has been performed. However, no study has been conducted on the effects of different frying methods on the physiochemical and nutritional properties of chub mackerel. Therefore, in this study, we evaluated the physiochemical and nutritional characteristics of deep fried, vacuum fried, and air fried chub mackerel. Thawing methods were compared and the best method was selected. High frequency defrosting (HFD) was used to thaw frozen fillet mackerel before frying. Response surface methodology (RSM) was used to optimize the temperature and frying time of the three frying methods. The physiochemical and nutritional characteristics, including volatile basic nitrogen (VBN), thiobarbituric acid-reactive substances (TBARS), $\mathrm{pH}$, overall acceptance, proximate, fatty acid, and amino acids of fried mackerel were investigated. The HFD exhibited the lowest number of drips with a short thawing time. The RSM showed that the optimum temperature and frying time for deep, vacuum, and air frying were $165^{\circ} \mathrm{C}$ for $3 \mathrm{~min}, 95^{\circ} \mathrm{C}$ for $7 \mathrm{~min}$, and $160{ }^{\circ} \mathrm{C}$ for $15 \mathrm{~min}$, respectively. Vacuum frying showed the lowest increase in VBN, TBARS, and $\mathrm{pH}$, and significantly $(p<0.05)$ differed from the others. It also resulted in increased amino acid and preserved fatty acid content. These findings suggest that vacuum frying is the best frying method which has little oxidation and can maintain nutrition. The results of this study could be applied in the fisheries industry to produce the best fried mackerel and preserve its high nutritive value.
\end{abstract}

Keywords: chub mackerel; deep frying; vacuum frying; air frying; nutrition profile

\section{Introduction}

Fish provides a source of nutrients that are essential for human health, including protein, omega- 3 fatty acids, calcium, and minerals such as zinc, potassium, iodine, and magnesium [1]. Omega-3 fatty acids, eicosapentaenoic acid (EPA), and docosahexaenoic acid (DHA) help maintain a healthy human heart [2] and brain [3]. Furthermore, nutrients from fish decrease the risk of depression, dementia, attention-deficit/hyperactivity disorder, diabetes, and Alzheimer's disease [4]. Tedeschi et al. [5] also reported that nutrition from fish can prevent inflammation and reduce the risk of arthritis.

Mackerel is a highly nutritious and sought after fish, which is widely consumed worldwide. Chub mackerel (Scomber japonicus) is a pelagic fish that can attain a full length of $50 \mathrm{~cm}$. According to the Food and Agriculture Organization [6], the chub mackerel live 
in the Indian and Pacific Oceans. It is rarely eaten raw and various cooking methods, such as boiling, smoking, braising, and frying can be used.

Frying is a popular method for cooking fish because it is the simplest and fastest method. It is a method of cooking food by submerging it in oil, also known as deep frying, that has been heated to a temperature high enough to brown the food's surface and partially or completely cook the food. During this process, lipids are used in direct contact with food as a heat transfer medium. Fried products have unique characteristics including enhanced flavor, crisp/firm outer coating, and a tender and juicy texture inside. Since oil becomes much hotter at normal atmospheric pressure than other cooking mediums, preparing food by frying is faster than other cooking methods.

The presence of oxygen, high temperature, and water in the frying process causes a number of reactions, the most notable of which are oxidation and polymerization. During the frying process, oxidation becomes a major issue, lowering the nutritional value of foods. Denaturation of proteins and low thermal stability of some essential amino acids, such as eicosapentaenoic acid (EPA), docosahexaenoic acid (DHA), and oleic acid, may contribute to the loss of nutritional value $[7,8]$. These conditions necessitate finding a low-oxidation frying method, particularly for the production of fried fish.

The high amount of oil that is absorbed by the food is a disadvantage of deep frying. The high temperature used during frying can also carbonize or burn the surface of food. Thus, several frying methods have been developed to minimize these disadvantages. Vacuum and air frying can be used instead of conventional frying. Vacuum frying is a frying process that uses atmospheric pressure ( $<50$ Torr); this is an efficient condition for frying food with the necessary degree of dehydration without excessive darkening or scorching [9]. Vacuum frying has been used in various industries to produce the best quality of products, such as fruits and vegetables. Frying in a vacuum fryer results in lower oxidation and higher nutritional value $[10,11]$ than other frying methods.

Unlike the previous two frying methods, air frying utilizes and circulates hot air to fry food, which decreases the absorption of oil in food [12]. Frying in an air fryer results in low calorie and fat content. Teruel et al. [13] reported that air frying can achieve the characteristic color of frying by deep frying with less oil absorption. Notably, many households believe that frying in an air fryer is healthier than frying in oil.

The effects of frying on the nutrition of mackerel have been reported by Oduro et al. [14] and Sébédio et al. [15]. They revealed that deep frying had an effect on the protein quality and stability of fatty acids in mackerel. However, no research has been published on the effect of different frying methods on the physiochemical and nutritional qualities of chub mackerel. Therefore, it is essential to know the best frying method that can maintain these qualities in chub mackerel.

In this study, we evaluated three different frying methods, namely deep, vacuum, and air frying, to determine the best frying method that could be adopted in fishery industries and used to produce high-quality fried mackerel with little loss of nutrition.

\section{Materials and Methods}

\subsection{Experimental Samples}

Fillet mackerel (S. japonicus) with an average mass of $76.78 \mathrm{~g}$ were obtained from EBADA Fishery Co., Ltd., (Busan, Korea) under frozen conditions.

\subsection{Drip Loss Analysis}

The filter paper wetness method was used to measure drip loss [16]. Three different thawing conditions were treated as the variables in this study: high-frequency defrosting (HFD), water thawing (WT), and air thawing (AT). Plastic bags were used to contain the mackerel in the water and air temperature thawing treatments. In total, four samples of frozen-fillet mackerel were used for each thawing method. For WT, samples were thawed in flowing tap water at $22-24{ }^{\circ} \mathrm{C}$, while for AT, samples were thawed at $18-20^{\circ} \mathrm{C}$. The HFD thawing method used the CHRFT-100 HFD machine (Chamco Co., Ltd., Busan, Korea) 
with an input power of $11 \mathrm{~kW}$ set at $27 \mathrm{MHz}$ for $10 \mathrm{~min}$. The quantitative filter paper No. 2 ( $55 \mathrm{~mm}$; Advantech, Tokyo, Japan) was used and weighed $(y)$ before being placed on the sample. During the thawing process, exudates were absorbed by the filter paper which was then weighed after the thawing process was complete $(x)$. The value of the exudate was expressed as the weight difference before and after thawing. The drip loss (\%) was quantified using the following formula:

$$
\text { Drip loss }(\%)=\frac{x-y}{x} \times 100
$$

\subsection{Frying Treatment}

Thawed samples were steak-sliced into a size of $5 \times 5 \mathrm{~cm}$ (width $\times$ length) and fried using one of three different frying methods: deep, vacuum, or air frying. The temperature and time required for frying were set based on the uncoded value of the response surface methodology (RSM). The deep and vacuum frying treatments were performed using sunflower oil as the frying medium. A WS-EFS20 electric fryer (Woosung Enterprise Co., Ltd., Seoul, Korea) was used at $137^{\circ} \mathrm{C}$ for $3 \mathrm{~min}, 145^{\circ} \mathrm{C}$ for 2 and $4 \mathrm{~min}, 165^{\circ} \mathrm{C}$ for 1,2 , and $3 \mathrm{~min}, 185^{\circ} \mathrm{C}$ for 2 and $4 \mathrm{~min}$, and $193{ }^{\circ} \mathrm{C}$ for $3 \mathrm{~min}$. For vacuum frying, a BT-1E vacuum fryer (Kiyomoto Co., Ltd., Nobeoka, Japan) was used at $88^{\circ} \mathrm{C}$ for $7 \mathrm{~min}, 90^{\circ} \mathrm{C}$ for 4 and $10 \mathrm{~min}, 95{ }^{\circ} \mathrm{C}$ for 3,7 , and $11 \mathrm{~min}, 100{ }^{\circ} \mathrm{C}$ for 4 and $10 \mathrm{~min}$, and $102{ }^{\circ} \mathrm{C}$ for $7 \mathrm{~min}$. Furthermore, an air fryer (EY2018KR, Ningbo Careline Electric Appliance Co., Ltd., Ningbo, China) was used at $132{ }^{\circ} \mathrm{C}$ for $15 \mathrm{~min}, 140{ }^{\circ} \mathrm{C}$ for 14 and $16 \mathrm{~min}, 160^{\circ} \mathrm{C}$ for 13,15 , and $16 \mathrm{~min}, 180^{\circ} \mathrm{C}$ for 14 and $16 \mathrm{~min}$, and $188^{\circ} \mathrm{C}$ for $15 \mathrm{~min}$.

\subsection{Volatile Basic Nitrogen (VBN) Analysis}

VBN was measured using the Conway micro diffusion method; 3rd distilled water was added to the fish at a ratio of 5:1 $(v / w)$ and homogenized using a vortex for $5 \mathrm{~min}$. After homogenization, the samples were filtered using filter paper No. 2. After obtaining the filtrate solutions, potassium carbonate was added to the outer chamber at a ratio of 1:1 $(v / v)$, and in the inner chamber, $0.01 \mathrm{M} \mathrm{H}_{2} \mathrm{SO}_{4}(1 \mathrm{~mL})$ was added. The chamber was then incubated at $37^{\circ} \mathrm{C}$ for $90 \mathrm{~min}$. Before titration using $0.01 \mathrm{~N} \mathrm{NaOH}$, Brunswick reagent (2-3 drops) was added to the inner chamber.

\subsection{Thiobarbituric Acid-Reactive Substances (TBARS) Analysis}

TBARS was measured by homogenizing $5 \mathrm{~g}$ of mackerel with $12.5 \mathrm{~mL}$ of TCA solution containing $20 \%$ trichloroacetic acid in $2 \mathrm{M}$ phosphoric acid and adjusted to $25 \mathrm{~mL}$ with 3rd distilled water. After homogenization, the sample was centrifuged at $1500 \mathrm{rpm}$ for $10 \mathrm{~min}$. The upper layer of each sample was collected and filtered. Next, $0.005 \mathrm{M}$ thiobarbituric acid solution was added to the supernatant at a ratio of 1:1 $(v / v)$ and incubated in a JSWB-22TL water bath (JS Research Inc., Gongju City, Korea) at $95{ }^{\circ} \mathrm{C}$ for $30 \mathrm{~min}$. After incubation, the samples were allowed to cool. A SPECTROstar Nano Microplate Reader (S/N601-0618, BMG Labtech Ltd., Ortenberg, Germany) was used to measure TBARS at $530 \mathrm{~nm}$; 3rd distilled water was used as the blank group and malondialdehyde bis (dimethyl acetal) was used as the standard.

\section{6. $\mathrm{pH}$ Analysis}

The sample was homogenized with 3rd distilled water at a ratio of 1:9 $(w / v)$ using an SHG-15D homogenizer (SciLab Co., Ltd., Seoul, Korea). The pH of the homogenized samples was measured using an ST 3100 pH meter (Ohaus Co., Parsippany, NJ, USA).

\subsection{Overall Acceptance}

The hedonic scale (1-10) was used according to the criteria used by Li et al. [17] to analyze the overall acceptance. "Remarkably dislike" was indicated by 1 and "extreme like" was indicated by 9 . The threshold value was 5 , and any sample with a score of less than this was considered unacceptable. Twenty-one panelists were included in this test. 


\subsection{Proximate Analysis}

Proximate parameters including calories, sodium, carbohydrates, sugars, dietary fiber, fat (trans fat and saturated fat), cholesterol, crude protein, vitamin D, iron, potassium, and calcium were measured following AOAC standard methods by the Research Institute of Agricultural Science, Chungnam National University (Daejeon, Korea).

\subsection{Fatty Acid Composition Analysis}

Fatty acids were extracted using ether and methylated into fatty acid methyl esters (FAMEs). A gas chromatography mass spectrometer (GCMS-QP2020, Shimadzu Co., Kyoto, Japan) and a DB-wax capillary column $(30 \mathrm{~m} \times 0.25 \mathrm{~mm}$ i.d., $0.25 \mathrm{~mm}$ film thickness, Agilent Technology, Santa Clara, CA, USA) were used to analyze FAMEs. A standard mixture (EN 14078, Paragon Scientific Ltd., Wirral, UK) was used to identify the peaks and calculate the response factor. The results were expressed as $\mathrm{g} / 100 \mathrm{~g}$ of dry matter.

\subsection{Amino Acid Analysis}

A Hitachi L-8900 amino acid analyzer (Hitachi High-Tech Corp., Tokyo, Japan) was used to measure the amino acids in the samples. Briefly, $6 \mathrm{~N} \mathrm{HCl}$ was used to hydrolyze the sample at $110{ }^{\circ} \mathrm{C}$ for $24 \mathrm{~h}$. After $24 \mathrm{~h}$, distilled water was added to remove $\mathrm{HCl}$, and the samples were dried twice. Before injection, the hydrolysate was diluted in $0.02 \mathrm{~N} \mathrm{HCl}$ filtered using a membrane filter. Amino acid standards were used to compare results.

\subsection{Statistical Analysis}

IBM SPSS (version 23.0; IBM Corp., Armonk, NY, USA) software was used to analyze drip loss, $\mathrm{pH}, \mathrm{VBN}, \mathrm{TBARS}$, and overall acceptance data using one-way analysis of variance (ANOVA) at a $95 \%$ level of probability $(p<0.05)$. Minitab v. 14.0 (Minitab Inc., Birmingham, UK) was used to analyze the RSM. Temperature and frying time were set as independent variables, while overall acceptance was set as the dependent variable.

\section{Results and Discussion}

\subsection{Drip Loss}

The drip loss of frozen mackerel was measured by quantifying the exudates absorbed by the filter papers. Three different thawing conditions resulted in different drip losses (Figure 1). The different thawing methods significantly affected the number of drip losses $(p<0.05)$ which ranged from $6.52 \%$ to $9.19 \%$. The lowest drip loss was observed with HFD, followed by water temperature, and air temperature. HFD was significantly different from the other thawing methods $(p<0.05)$. Similar results were reported by Negara et al. [18] and Tirtawijaya et al. [19]. The use of HFD successfully decreased the number of drip losses compared to conventional thawing methods.

The thawing time of HFD was shorter than water temperature and air temperature, and this minimized the damage to the cell membranes of cells in mackerel and resulted in reduced drip loss [20,21]. Mechanical damage that causes recrystallization can be decreased by rapid thawing [21].

Drip loss leads to a change in position of water molecules in fish muscle, thus, resulting in stringy, dry, and flavorless fish. Moreover, drip loss also increases the loss of some nutrients, such as minerals, proteins, and vitamins [22], and is linked to protein denaturation. The high drip loss decreases sensory parameters such as texture, attractiveness, and appearance [23]. The lower drip loss observed with HFD indicates that applying HFD for thawing is an effective method to decrease drip loss. Therefore, thawing using the HFD method for frozen mackerel was chosen for use in the next steps of the present study. 


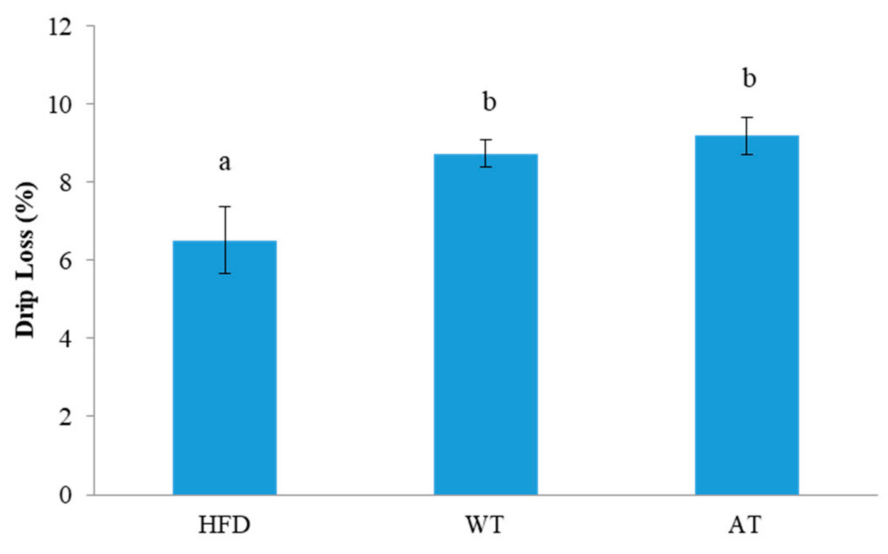

Figure 1. Drip loss analysis of 12 samples of frozen-fillet chub mackerel (Scomber japonicus) in different thawing methods. Data are presented as mean $\pm \mathrm{SD}$. Different superscript letters $(\mathrm{a}, \mathrm{b})$ show significantly different values according to Duncan's test $(p<0.05)$.

\subsection{Optimum Frying Conditions}

RSM was used to optimize the frying conditions for all methods. The independent variables in this study were temperature $\left(X_{1}\right)$ and frying time $\left(X_{2}\right)$, and the dependent variable was overall acceptance $(\mathrm{Y})$. The overall acceptance score reflected the sensory properties of fried mackerel across the three different frying methods. The model of this study was developed as a five-level central composite design. The design generated 11 runs consisting of low, central, and high factor levels. These conditions yielded the determination of frying time and temperature required in each frying method. The combination of optimum temperature, time, and overall acceptance resulted in the optimum frying conditions.

Table 1 displays the model equations for the three different frying methods used to prepare the mackerel. Using these models, the overall acceptance score of the fried mackerel (irrespective of frying method), temperature, and frying time were estimated. The $\mathrm{R}^{2}$ of deep, vacuum, and air frying showed that the models were significant at a $95 \%$ confidence level $(p<0.05)$. This indicates that the models were suitable and adequate for predicting the temperature and frying time in the three different frying methods for mackerel.

Table 1. Response surface model equations of chub mackerel (Scomber japonicus) for different frying methods.

\begin{tabular}{ccc}
\hline Treatment & Quadratic Polynomial Model Equations & $\mathbf{R}^{\mathbf{2}}$ \\
\hline Deep fry & $0.417 \mathrm{X}_{1}+3.63 \mathrm{X}_{2}-0.001258 \mathrm{X}_{1}^{2}-0.500 \mathrm{X}_{2}{ }^{2}-0.0026 \mathrm{X}_{1} \mathrm{X}_{2}$ & $97.8 \%$ \\
Vacuum fry & $9.02 \mathrm{X}_{1}+4.56 \mathrm{X}_{2}-0.04605 \mathrm{X}_{1}^{2}-0.1376 \mathrm{X}_{2}{ }^{2}-0.0250 \mathrm{X}_{1} \mathrm{X}_{2}$ & $96.9 \%$ \\
Air fry & $0.348 \mathrm{X}_{1}+16.78 \mathrm{X}_{2}-0.001320 \mathrm{X}_{1}{ }^{2}-0.580 \mathrm{X}_{2}{ }^{2}+0.0046 \mathrm{X}_{1} \mathrm{X}_{2}$ & $97.4 \%$ \\
\hline
\end{tabular}

Three-dimensional response surface plots of the three frying methods showed an increase in the overall acceptance score of the mackerel with an increase in temperature and frying time until an optimum condition was attained (Figure 2). At temperatures over $165^{\circ} \mathrm{C}$ for $3 \mathrm{~min}$, the deep-fried mackerel had a gold-brown color and were overcooked. On the contrary, low temperature and short frying time resulted in uncooked mackerel. Similar phenomena were also observed with vacuum and air frying. During vacuum frying, using temperature over $95^{\circ} \mathrm{C}$ for $7 \mathrm{~min}$ resulted in low moisture, and the fish became crispy. Thus, mackerel fried over or above the optimum conditions had a low overall acceptance score. Mackerel air fried at temperatures over $160^{\circ} \mathrm{C}$ for $15 \mathrm{~min}$ had low moisture and a bitter taste, also resulting in a low overall acceptance score. The overall acceptance score started to decline beyond $165^{\circ} \mathrm{C}$ and $3 \mathrm{~min}$ for deep frying (Figure 2a), $95^{\circ} \mathrm{C}$ and $7 \mathrm{~min}$ for vacuum frying (Figure $2 \mathrm{~b}$ ), and $160^{\circ} \mathrm{C}$ and $15 \mathrm{~min}$ for air frying (Figure 2c). Therefore, these conditions represent the optimum temperature and frying time for these 
three frying methods. The mackerel were cooked under these conditions and analyzed in subsequent experiments.

The best combination of independent and dependent variables from RSM resulted in the optimum temperature and time for frying mackerel in three frying methods [24,25]. Under optimal conditions, mackerel is neither overcooked nor undercooked. Our results indicate that RSM can optimize the temperature and time for frying mackerel to obtain a high overall acceptance score.

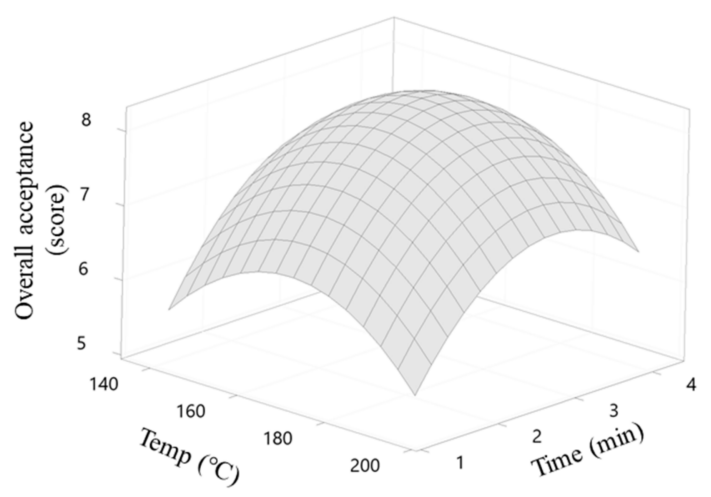

(a)

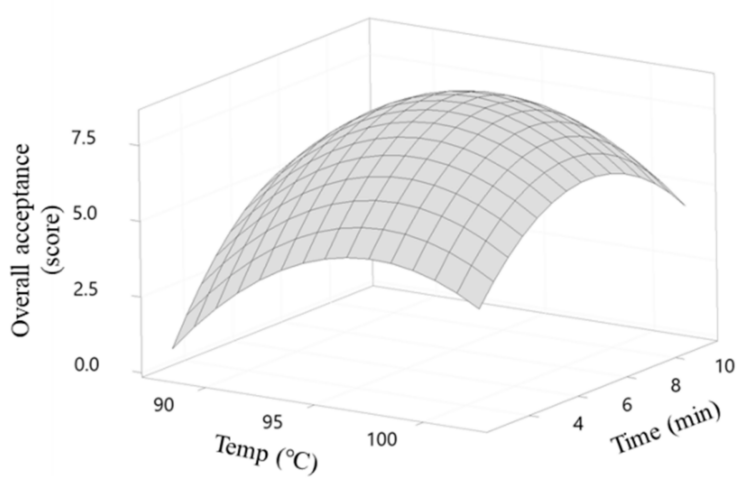

(b)

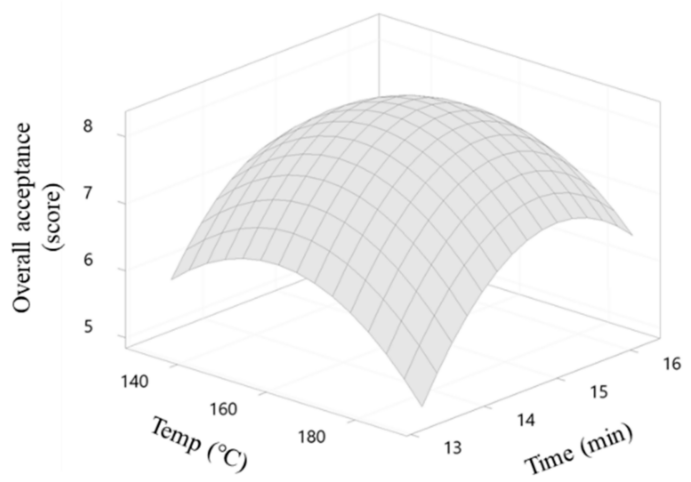

(c)

Figure 2. Three-dimensional response surface plots of (a) deep fried, (b) vacuum fried, and (c) air fried chub mackerel (Scomber japonicus).

\subsection{Physiochemical Properties}

Physiochemical properties were analyzed to test the effects of the three frying methods on chub mackerel. Chemical properties (VBN, TBARS, and $\mathrm{pH}$ ) were evaluated and used to indicate the oxidation of nutrients during frying.

Figure 3 shows the results of VBN for the three frying methods. VBN is a critical parameter for determining the freshness of seafood products. This parameter is also used to assess the quality of seafood [26]. Frying affected an increase in VBN, and there was a significant $(p<0.05)$ difference between the VBN in raw mackerel and that in mackerel across all three frying methods. El-Sherif et al. [27] reported similar results for mullet fish. The highest increase in VBN was observed with deep frying, followed by with air and vacuum frying. The high value of VBN in deep and air fried fish was due to high temperatures, which led to an increase in the volatilization of some nitrogen compounds [24]. Moreover, the degradation of proteins and amines that form trimethylamine-N-oxide, trimethylamine, dimethylamine, formaldehyde, and the deamination of adenine nucleotides affects the increase in VBN [28-30]. Marimuthu et al. [31] showed that increase in temperature leads 
to reduction in proteins, with the proteins converting to volatile nitrogen. Meanwhile, compared with deep and air frying, vacuum frying operated at a low temperature. This resulted in low VBN at a significant difference $(p<0.05)$ from deep and air frying.

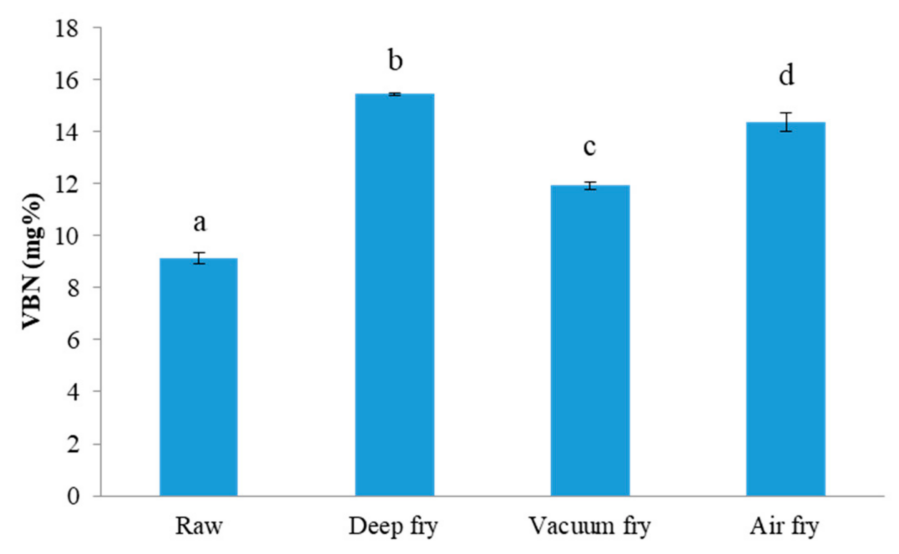

Figure 3. Volatile basic nitrogen (VBN) of chub mackerel (Scomber japonicus) in different frying methods. Data are presented as mean \pm SD. Different superscript letters (a-d) show significantly different values according to Duncan's test $(p<0.05)$.

The TBARS results after frying are shown in Figure 4. The TBARS value is a measure of lipid oxidation because it quantifies the amount of MDA formed during the initial reaction of PUFA with oxygen [32,33]. The oxidation of lipids in fishery products is a major cause of spoilage. The number of TBARS in fried mackerel increased and was significantly different $(p<0.05)$ to that in raw mackerel after frying across all methods. Our results agree with those of Weber et al. [34], who reported an increase in TBARS after frying. Air frying showed the highest increase in TBARS, followed by deep and vacuum frying. Since high temperatures can increase the number of oxidations, deep and air frying oxidized more lipids than vacuum frying which operated at a low temperature. Frying time also affects the rate of lipid oxidation. Air frying takes the longest frying time and, thus, has a high value of TBARS. Meinert et al. [35] reported that the high temperature and time results in a high amount of lipid oxidation, which also generates peptides and amino acids as an effect of the proteolytic reaction, and causes a decrease in the oxidated compounds and malonaldehyde content.

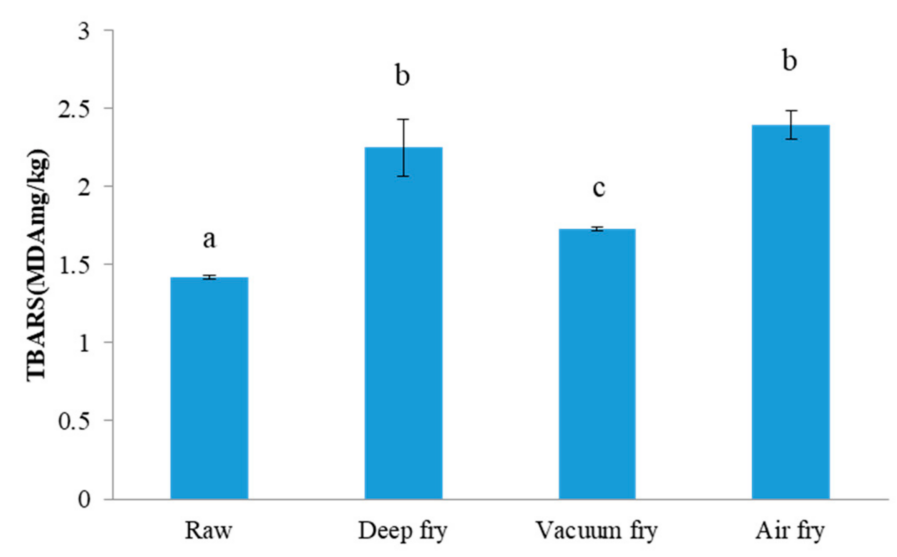

Figure 4. Thiobarbituric acid-reactive substances (TBARS) produced by chub mackerel (Scomber japon$i c u s$ ) after using different frying methods. Data are presented as mean \pm SD. Different superscript letters $(\mathrm{a}-\mathrm{c})$ show significantly different values according to Duncan's test $(p<0.05)$. 
The effects of different frying methods on $\mathrm{pH}$ are shown in Figure 5. The $\mathrm{pH}$ of fried mackerel increased in all frying methods and was significantly $(p<0.05)$ different from that of raw mackerel. Similar results were reported by El-Sherif et al. [27]. They reported that the $\mathrm{pH}$ of tilapia and mullet fish increased after frying. Air frying had the highest increase in $\mathrm{pH}$, followed by deep and vacuum frying. The increase in $\mathrm{pH}$ during frying may be due to the formation of some basic compounds as a result of amino acid degradation [36]. Since air frying circulates hot air due to a high temperature, there is increased hydrogen bond breakage and electrostatic interactions that impact the highest increase in $\mathrm{pH}$ [37].

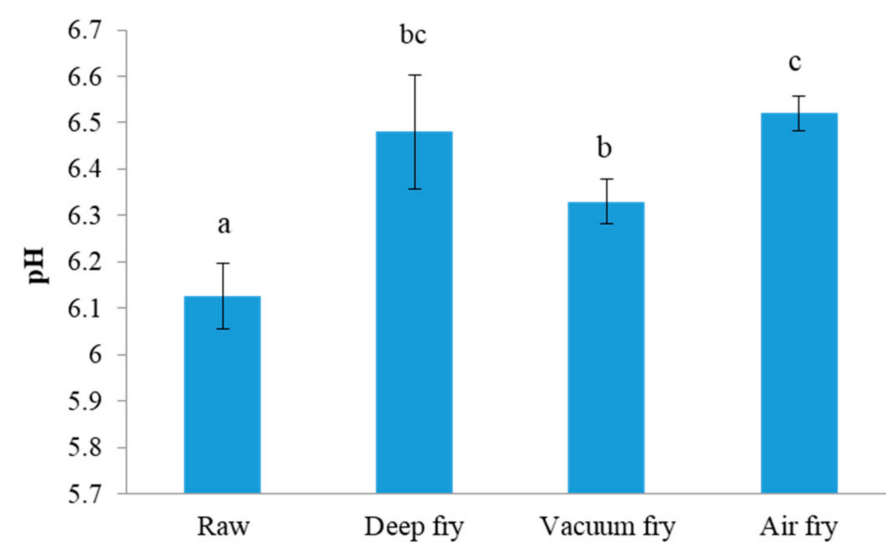

Figure 5. $\mathrm{pH}$ of chub mackerel (Scomber japonicus) in different frying methods. Data are presented as mean \pm SD. Different superscript letters $(a-c)$ show significantly different values according to Duncan's test $(p<0.05)$.

As a physical parameter, overall acceptance was observed to determine the effects of different frying methods on mackerel, and the results are shown in Figure 6. Deep frying and air frying yielded similar results, while vacuum frying had the lowest score, possibly due to the low moisture. However, the overall acceptance of vacuum frying was still classified from "like slightly" to "like very much". This indicates that despite the overall acceptance score, vacuum frying was still acceptable to the panelists. Moreover, the overall acceptance score of vacuum frying was the best score obtained from optimization using RSM. Reduction of temperature during frying using vacuum frying also decreased the overall acceptance due to uncooked samples.

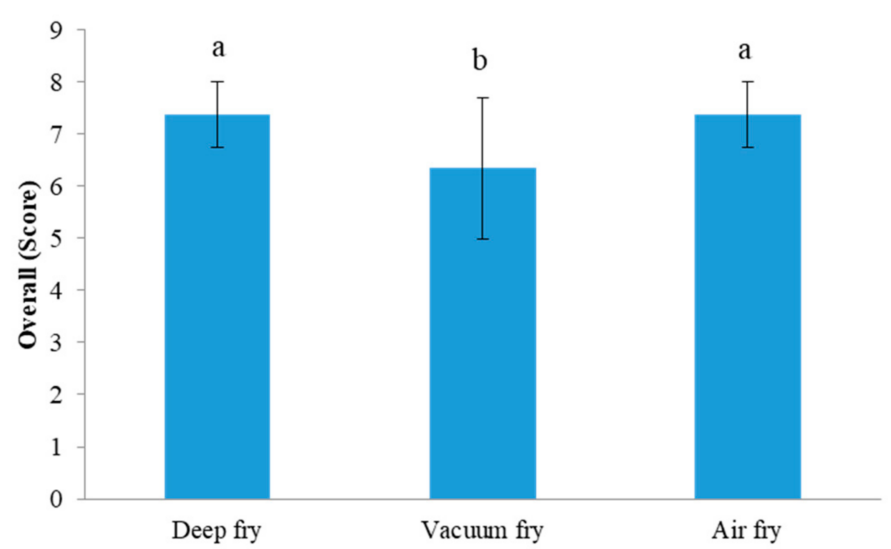

Figure 6. Sensory analysis of chub mackerel (Scomber japonicus) in different frying methods. Data are presented as mean $\pm \mathrm{SD}$. Different superscript letters $(a, b)$ show significantly different values according to Duncan's test $(p<0.05)$.

According to the results of analyses of chemical properties, vacuum frying resulted in the lowest increase in TBARS, VBN, and $\mathrm{pH}$, and showed a significant $(p<0.05)$ difference 
compared with other methods. This might be due to its closed system which can lower the boiling points of frying oil and moisture. Under these conditions, the product is cooked at low temperature and oxygen [38] which results in a low oxidation rate. Furthermore, frying in this condition could preserve the natural color and flavor of the product and have fewer adverse effects on oil quality [39].

Our results show that vacuum frying is the best method for frying chub mackerel with less oxidation. Moreover, vacuum frying can maintain nutrition, resulting in good product quality. These findings could be applied to produce highly nutritious fried mackerel with efficient temperature and frying time in the fisheries industry. Since vacuum frying exhibited the best results in terms of physiochemical properties, particularly chemical properties, we further evaluated the nutritional qualities of vacuum fried mackerel.

\subsection{Nutritional Quality}

The frying process affected the nutritional value of the fried mackerel compared to raw mackerel (Table 2). The frying process increased calories, carbohydrates, sugar, fat, cholesterol, crude protein, and calcium content. These results are consistent with those of Mariscal and Bouchon [40] and Kemp et al. [41], who found an increase in the nutritional value of vacuum fried products. This might be caused by the migration of fats from the oil used for frying; this improves the nutrients and flavor of the fried product [42,43]. Furthermore, increase in fat content also occurred by the absorption of oil into fried products [44]. Similarly, Germaine et al. [45] observed an increase in crude fat and protein content in Cameroonian mackerel (Scomber scombrus) after frying.

Table 2. Nutritional value in $100 \mathrm{~g}$ of chub mackerel (Scomber japonicus) after vacuum frying.

\begin{tabular}{cccc}
\hline Parameters & Unit & Raw & Treatment \\
\cline { 3 - 4 } & & 248.36 & 390.79 \\
Calories & $\mathrm{kcal}$ & 0.06 & 0.01 \\
Sodium & $\mathrm{mg}$ & 0.06 & 0.88 \\
Carbohydrate & $\mathrm{g}$ & 0.00 & 0.13 \\
Sugars & $\mathrm{g}$ & 5.32 & 2.44 \\
Dietary fiber & $\mathrm{g}$ & 1.45 & 2.32 \\
Crude fat & $\mathrm{g}$ & 18.44 & 29.95 \\
Fat & $\mathrm{g}$ & 0 & 0 \\
Trans fat & $\mathrm{g}$ & 9.96 & 5.63 \\
Saturated fat & $\mathrm{g}$ & 60.98 & 117.1 \\
Cholesterol & $\mathrm{mg}$ & 20.54 & 29.43 \\
Crude protein & $\mathrm{g}$ & 0 & 0 \\
Vitamin D & $\mu \mathrm{g}$ & 1.43 & 1.2 \\
Iron & $\mathrm{mg}$ & 0.31 & 0.29 \\
Potassium & $\mathrm{g}$ & 0.03 & 0.02 \\
Calcium & $\mathrm{g}$ & 71.36 & 23.98 \\
Moisture & $\%$ & &
\end{tabular}

In contrast, dietary fibers, saturated fats, potassium, and moisture decreased during frying. This may be caused by the increasing oil temperature and the transfer of heat into the product's core. As the product approaches the boiling point, water evaporates and moisture decreases. Saturated fats and fibers are also oxidized during the frying process.

The decrease in moisture and the increase in crude fat and protein in fried mackerel indicated that the loss of water is the main point during frying. Brugiapaglia and Destefanis [7] also found similar results. Protein denaturation during frying also contributes to the evaporation of the water entrapped within the structures of the protein [46].

The evaporation of water and oxidation of saturated fats affects nutritional value of fried products. However, the composition of unsaturated fatty acids and essential amino acids could be maintained after frying, as described below. 


\subsection{Fatty Acid Composition}

The effects of frying on fatty acids are displayed in Table 3. The results show that frying decreased both the saturated and unsaturated fatty acids. This is consistent with the work of Mekonnen et al. [47], who reported a decrease in fatty acid content in fish muscle after frying. The decrease in fatty acids might be due to the oxidation of fat during frying.

Table 3. Fatty acid profile (g/100 g) of chub mackerel (Scomber japonicus) after vacuum frying.

\begin{tabular}{|c|c|c|}
\hline \multirow{2}{*}{ Fatty Acids } & \multicolumn{2}{|c|}{ Treatment } \\
\hline & Raw & Vacuum Fry \\
\hline Capric acid & 0.00 & 0.00 \\
\hline Lauric acid & 0.01 & 0.00 \\
\hline Myristic acid & 0.42 & 0.14 \\
\hline Pentadecanoic acid & 0.08 & 0.02 \\
\hline Palmitic acid & 2.24 & 0.68 \\
\hline Magaric acid & 0.10 & 0.02 \\
\hline Stearic acid & 0.67 & 0.19 \\
\hline Arachidic acid & 0.08 & 0.00 \\
\hline Heneicosylic acid & 0.02 & 0.00 \\
\hline Behenic acid & 0.00 & 0.01 \\
\hline Lignoceric acid & 0.16 & 0.01 \\
\hline Saturated fatty acid & 3.77 & 1.06 \\
\hline Myristoleic acid & 0.02 & 0.01 \\
\hline Pentadecenoic acid & 0.01 & 0.01 \\
\hline Palmitoleic acid & 0.43 & 0.11 \\
\hline Magaoleic acid & 0.09 & 0.01 \\
\hline Oleic acid & 2.40 & 2.39 \\
\hline Linoleic acid & 0.17 & 0.63 \\
\hline$\gamma$-Linolenic acid & 0.01 & 0.03 \\
\hline Linolenic acid & 0.09 & 0.29 \\
\hline Eicosenoic acid & 0.31 & 0.15 \\
\hline Eicosadienoic acid & 0.03 & 0.06 \\
\hline Dihomo $\delta$-Linoleicacid & 0.00 & 0.01 \\
\hline Eicosatrienoicacid & 0.00 & 0.01 \\
\hline Arachidonic acid & 0.11 & 0.15 \\
\hline EPA & 0.69 & 0.16 \\
\hline Erucic acid & 0.24 & 0.01 \\
\hline Docosadienoicacid & 0.00 & 0.01 \\
\hline Nervonic acid & 0.07 & 0.01 \\
\hline DPA & 0.00 & 0.03 \\
\hline DHA & 1.51 & 0.37 \\
\hline Unsaturated fatty acid & 6.19 & 4.44 \\
\hline
\end{tabular}

EPA, DHA, and oleic acids, which are essential fatty acids in humans, also decreased after frying. This reduction might be caused by the low oxidative and thermal stability of these compounds [8]. In this study, the increasing of temperature would oxidize EPA, DHA, and oleic acids during frying.

Fatty acids are easy to oxidize; hence, their reduction is an inevitable consequence of frying. The increasing temperature and the use of oil are the main factors that lead to the oxidation of fatty acids. In this study, the optimal temperature of vacuum frying was $95^{\circ} \mathrm{C}$. At this temperature, saturated and unsaturated fatty acids and water in the chub mackerel could be oxidized. Although frying decreased the number of fatty acids, the fried mackerel still contained essential fatty acids such as EPA and DHA, which can reduce inflammation and protect against cardiovascular disease and neurodegeneration [48]. The fatty acid content in the fried mackerel indicated that the product is highly nutritious, thereby suggesting its potential to contribute to daily fatty acid requirements. 


\subsection{Amino Acid Composition}

Non-essential amino acids such as alanine, aspartic acid, cysteine, glutamic acid, glycine, proline, serine, and tyrosine were identified in raw and fried mackerel. In addition, essential amino acids such as arginine, histidine, isoleucine, leucine, lysine, methionine, phenylalanine, threonine, tryptophan, and valine were quantified in both raw and fried mackerel (Table 4).

Table 4. Amino acid profile (g/100 g) of chub mackerel (Scomber japonicus) after vacuum frying.

\begin{tabular}{ccc}
\hline Amino Acid & \multicolumn{2}{c}{ Treatment } \\
\cline { 2 - 3 } & Raw & Vacuum Fry \\
\hline Alanine & 1.22 & 1.63 \\
Aspartic acid & 1.84 & 2.43 \\
Cystine & 0.28 & 0.33 \\
Glutamic acid & 2.6 & 3.57 \\
Glycine & 1.10 & 1.41 \\
Proline & 0.76 & 1.02 \\
Serine & 0.74 & 1.07 \\
Tyrosine & 0.43 & 0.71 \\
Total Non-Essential & $\mathbf{8 . 9 7}$ & $\mathbf{1 2 . 1 7}$ \\
Arginine & 1.15 & 1.6 \\
Histidine & 1.09 & 1.12 \\
Isoleucine & 0.87 & 1.14 \\
Leucine & 1.54 & 2.13 \\
Lysine & 1.78 & 2.4 \\
Methionine & 0.83 & 1.06 \\
Phenylalanine & 0.75 & 0.99 \\
Threonine & 0.88 & 1.22 \\
Tryptophan & 0.15 & 0.22 \\
Valine & 1.05 & 1.33 \\
Total Essential & $\mathbf{1 0 . 0 9}$ & $\mathbf{1 3 . 2 1}$ \\
\hline
\end{tabular}

Frying chub mackerel resulted in an increase in amino acid content. The increase in amino acids might be due to leaching of the water and the absorption of oil during the frying process. This decreases the moisture content and subsequently increases the number of amino acids and other nutrients. Similar results indicate that the formation of new products similar to proteins during frying also affects the increase of amino acids [49,50].

The increase in amino acids is also triggered by heat and mass transfer during the process. In this study, the samples were immersed in hot oil under vacuum conditions, which led to the evaporation of water, resulting in an increase in amino acids. Amino acids give flavor and taste to seafood and fishery products. The sweet taste was affected by glycine, alanine, and glutamic acid. Ozden [51] reported that glycine, alanine, aspartic acid, and glutamic acid are also effective in the flavor and taste of raw and marinated fish. The increase in amino acids not only impacts the quality of the product but also human health.

\section{Conclusions}

This is the first study to report on vacuum and air frying of chub mackerel. Three different thawing methods exhibited variations in drip loss and thawing time. The drip loss and thawing time of frozen mackerel could be decreased by HFD, which resulted in better raw material. Based on the RSM, the optimal temperature and frying time for deep, vacuum, and air frying were $165^{\circ} \mathrm{C}$ for $3 \mathrm{~min}, 95^{\circ} \mathrm{C}$ for $7 \mathrm{~min}$, and $160{ }^{\circ} \mathrm{C}$ for 15 min, respectively. The optimum conditions for frying were chosen according to the best combination of both temperature and frying time that resulted in the highest score of overall acceptance. Three different frying methods affected the physiochemical qualities of chub mackerel. Vacuum frying exhibited the lowest VBN, TBARS, and $\mathrm{pH}$, and was significantly different from the other methods. Moreover, vacuum frying maintained 
essential unsaturated fatty acids (EPA and DHA) and increased the number of amino acids after frying. These findings suggest that vacuum frying is the best frying method with little loss of physiochemical and nutritional quality. Our results could be utilized in fishery industries to produce high-quality fried mackerel.

Author Contributions: Conceptualization, J.-S.C.; methodology, B.F.S.P.N., M.-J.L., and W.-H.C.; formal analysis, J.-H.S.; data curation, J.-H.S.; writing —original draft preparation, B.F.S.P.N. and G.T.; writing—review and editing, J.-S.C.; visualization, J.S.K.; supervision, J.S.C. and J.-S.K. All authors have read and agreed to the published version of the manuscript.

Funding: This study was funded by the Ministry of Oceans and Fisheries, Korea, under the project no. PJT200885 entitled "Development and commercialization of traditional seafood products based on the Korean coastal marine resources".

Institutional Review Board Statement: Not applicable.

Informed Consent Statement: Not applicable.

Data Availability Statement: Data supporting reported results are available upon request.

Conflicts of Interest: The authors declare no conflict of interest.

\section{References}

1. Pal, J.; Shukla, B.N.; Maurya, A.K.; Verma, H.O.; Pandey, G.; Amitha, A. A review on role of fish in human nutrition with special emphasis to essential fatty acid. Int. J. Fish. Aquat. Stud. 2018, 6, 427-430.

2. Kris-Etherton, P.M.; Harris, W.S.; Appel, L.J. Fish consumption, fish oil, omega-3 fatty acids, and cardiovascular disease. Circulation 2002, 106, 2747-2757. [CrossRef] [PubMed]

3. Swanson, D.; Block, R.; Mousa, S.A. Omega-3 Fatty Acids EPA and DHA: Health Benefits Throughout Life. Adv. Nutr. 2012, 3, 1-7. [CrossRef]

4. Lange, K.W. Omega-3 fatty acids and mental health. Glob. Health J. 2020, 4, 18-30. [CrossRef]

5. Tedeschi, S.K.; Bathon, J.M.; Giles, J.T.; Lin, T.C.; Yoshida, K.; Solomon, D.H. The relationship between fish consumption and disease activity in rheumatoid arthritis. Arthritis Care Res. 2018, 70, 327-332. [CrossRef] [PubMed]

6. Food and Agriculture Organization of the United Nations (FAO-UN). Food and Agriculture Organization of the United Nations (FAO-UN) 2010-2018, Fisheries Global Information System (FAO-FIGIS). 2018. Available online: http://www.fao.org/fishery/ (accessed on 30 April 2021).

7. Brugiapaglia, A.; Destefanis, G. Influence of the housing system on meat quality of double muscled Piemontese young bulls. Livest. Sci. 2012, 145, 73-78. [CrossRef]

8. Arab-Tehrany, E.; Jacquot, M.; Gaiani, C.; Imran, M.; Desobry, S.; Linder, M. Beneficial effects and oxidative stability of omega-3 long-chain polyunsaturated fatty acids. Trends Food Sci. Technol. 2012, 25, 24-33. [CrossRef]

9. Moreira, R.G. Vacuum frying versus conventional frying-An overview. Eur. J. Lipid Sci. Tech. 2014, 116, 723-734. [CrossRef]

10. Shyu, S.L.; Hwang, L.S. Effects of processing conditions on the quality of vacuum fried apple chips. Food Res. Int. 2001, 34, 133-142. [CrossRef]

11. Dueik, V.; Moreno, M.C.; Bouchon, P. Microstructural approach to understand oil absorption during vacuum and atmospheric frying. J. Food Eng. 2012, 111, 528-536. [CrossRef]

12. Ferreira, F.S.; Sampaio, G.R.; Keller, L.M.; Sawaya, A.C.H.F.; Chavez, D.W.H.; Torres, E.A.F.S.; Saldanha, T. Impact of air frying on cholesterol and fatty acids oxidation in Sardines: Protective effects of aromatic herbs. J. Food Sci. 2017, 82, 2823-2831. [CrossRef] [PubMed]

13. Teruel, M.R.; Gordon, M.; Linares, M.B.; Garrido, M.D.; Ahromrit, A.; Niranjan, K. A Comparative study of the characteristics of french fries produced by deep fat frying and air frying. J. Food Sci. 2015, 80, 349-358. [CrossRef]

14. Oduro, F.A.; Choi, N.D.; Ryu, H.S. Effects of cooking conditions on the protein quality of Chub Mackerel Scomber japonicus. Fish. Aquat. Sci. 2011, 14, 257-265. [CrossRef]

15. Sébédio, J.L.; Ratnayake, W.M.N.; Ackman, R.G.; Prevost, J. Stability of polyunsaturated omega-3 fatty acids during deep fat frying of Atlantic mackerel (Scomber scombrus L.). Food Res. Int. 1993, 26, 163-172. [CrossRef]

16. Kauffman, R.G.; Eikelenboom, G.; van der Wal, P.G.; Merkus, G.; Zaar, M. The use of filter paper to estimate drip loss of porcine musculature. Meat Sci. 1986, 18, 191-200. [CrossRef]

17. Li, M.; Wang, W.; Fang, W.; Li, Y. Inhibitory effects of chitosan coating combined with organic acids on Listeria monocytogenes in refrigerated ready-to-eat shrimps. J. Food Prot. 2013, 76, 1377-1383. [CrossRef] [PubMed]

18. Negara, B.; Kim, S.; Sohn, J.; Kim, J.-S.; Choi, J.-S. Application of high-frequency defrosting, superheated steam, and quick-freezing treatments to improve the quality of seafood home meal replacement products consisting of the Adductor Muscle of Pen Shells and Common Squid Meat. Appl. Sci. 2021, 11, 2926. [CrossRef] 
19. Tirtawijaya, G.; Kim, S.R.; Cho, W.H.; Sohn, J.H.; Kim, J.-S.; Choi, J.-S. Development of a Home Meal Replacement Product Containing Braised Mackerel (Scomber japonicus) with Radish (Raphanus sativus). Foods 2021, 10, 1135. [CrossRef]

20. Venugopal, V. Seafood Processing Adding Value through Quick Freezing, Retortable Packaging, and Cook-Chilling; Taylor \& Francis: New York, NY, USA, 2006; p. 485.

21. Alizadeh, E.; Chapleau, N.; De Lamballerie, M.; LeBail, A. Effects of freezing and thawing processes on the quality of Atlantic salmon (Salmo salar) fillets. J. Food Sci. 2007, 72, 279-284. [CrossRef]

22. Gokoglu, N.; Yerlikaya, P.; Cengiz, E. Effects of cooking methods on the proximate composition and mineral contents of rainbow trout (Oncorhynchus mykiss). Food Chem. 2004, 84, 19-22. [CrossRef]

23. Otto, G.; Roehe, R.; Looft, H.; Thoelking, L.; Kalm, E. Comparison of different methods for determination of drip loss and their relationships to meat quality and carcass characteristics in pigs. Meat Sci. 2004, 68, 401-409. [CrossRef]

24. Beggs, K.L.H.; Bowers, J.A.; Brown, D. Sensory and physical characteristics of reduced-fat turkey frankfurters with modified corn starch and water. J. Food Sci. 1997, 62, 1240-1244. [CrossRef]

25. Pappa, I.C.; Bloukas, J.G.; Arvanitoyannis, I.S. Optimisation of salt, olive oil and pectin for low-fat frankfurters produced by replacing pork backfat with olive oil. Meat Sci. 2000, 56, 81-88. [CrossRef]

26. Yildiz, P.O. Effect of essential oils and packaging on hot smoked rainbow trout during storage. J. Food Process. Preserv. 2015, 39, 806-815. [CrossRef]

27. El-Sherif, S.A.; Ibrahim, S.M.; Abou-Taleb, M. Relationship between frozen pre-storage period on raw Tilapia and Mullet fish and quality criteria of its cooked products. Egypt. J. Aquat. Res. 2011, 37, 183-189.

28. Chen, H.Z.; Zhang, M.; Bhandari, B.; Yang, C.H. Development of a novel colorimetric food package label for monitoring lean pork freshness. LWT Food Sci. Technol. 2019, 99, 43-49. [CrossRef]

29. Howgate, P. A critical review of total volatile bases and trimethylamine as indices of freshness of fish. Part 1. Determination. Electron. J. Environ. Agric. Food Chem. 2010, 9, $29-57$.

30. Servillo, L.; D’onofrio, N.; Giovane, A.; Casale, R.; Cautela, D.; Castaldo, D.; Iannaccone, F.; Neglia, G.; Campanile, G.; Balestrieri, M.L. Ruminant meat and milk contain delta-valerobetaine, another precursor of trimethylamine N-oxide (TMAO) like gamma-butyrobetaine. Food Chem. 2018, 260, 193-199. [CrossRef]

31. Marimuthu, K.; Thilaga, M.; Kathiresan, S.; Xavier, R.; Mas, R.H.M.H. Effect of different cooking methods on proximate and mineral composition of striped snakehead fish (Channa striatus). J. Food Sci. Technol. 2012, 49, 373-377. [CrossRef]

32. Rezaei, M.; Hosseini, S.F.; Langrudi, H.E.; Safari, R.; Hosseini, S.V. Effect of delayed icing on quality changes of iced rainbow trout (Oncorhynchus mykiss). Food Chem. 2008, 106, 1161-1165. [CrossRef]

33. Pyrgotou, N.; Giatrakou, V.; Ntzimani, A.; Savvaidis, I.N. Quality assessment of salted, modified atmosphere packaged rainbow trout under treatment with oregano essential oil. J. Food Sci. 2010, 75, 406-411. [CrossRef]

34. Weber, J.; Bochi, V.C.; Ribeiro, C.P.; Victório, A.M.; Emanuelli, T. Effect of different cooking methods on the oxidation, proximate and fatty acid composition of silver catfish (Rhamdia quelen) fillets. Food Chem. 2008, 106, 140-146. [CrossRef]

35. Meinert, L.; Andersen, L.T.; Bredle, W.L.P.; Bjergegaard, C.; Aaslyng, M.D. Chemical and sensory characterization of pan-fried pork flavour: Interactions between rawmeat quality, ageing and frying temperature. Meat Sci. 2007, 75, 229-242. [CrossRef]

36. Ruiz-Capillas, C.; Moral, A. Correlation between biochemical and sensory quality indices in Hake stored in ice. Food Res. Int. 2001, 34, 441-447. [CrossRef]

37. Desrosier, N.W.; Tressler, D.K. Fundamentals of Food Freezing; Avi Publishing Company: Westport, CT, USA, 1977; Chapter 8; pp. 318-356.

38. Hidaka, T.; Fukuda, N.; Sakamoto, K. Evaluation of Quality of Oils and Fats Used in Vacuum Frying. Bull. Fac. Agric. 1991, 38, 35-38.

39. Kato, E.; Sato, K. Vacuum Frying Tempeh. Bull. Fac. Agric. 1991, 88, 25-32.

40. Mariscal, M.; Bouchon, P. Comparison between atmospheric and vacuum frying of apple slices. Food Chem. 2008, 107, 1561-1569. [CrossRef]

41. Kemp, S.E.; Hollowood, T.; Hort, J. Sensory Evaluation: A Practical Handbook; John Wiley \& Sons Inc.: New York, NY, USA, 2009; p. 208.

42. Fan, L.P.; Zhang, M.; Mujumdar, A.S. Vacuum frying of carrot chips. Dry. Technol. 2005, 23, 645-656. [CrossRef]

43. Tarmizi, A.H.A.; Niranjan, K. Post-frying oil drainage from potato chips and French fries. A comparative study of atmospheric and vacuum drainage. Food Bioproc. Technol. 2013, 6, 489-497. [CrossRef]

44. Setyawan, A.D.; Sugiyarto, S.; Solichatun, S.; Susilowati, A. Review: Physical, physical chemistries, chemical and sensorial characteristics of the several fruits and vegetable chips produced by low-temperature of vacuum frying machine. Nusant. Biosci. 2013, 5, 86-103.

45. Germaine, M.J.E.; Tsafack, A.L.S.; Maboune, A.S.; Eyenga, E.F.; Sophie, N.E.; Bongse, K.P. Quality evaluation of local Cameroonian mackerel (Scomber scombrus) processed by different methods. Int. J. Food Sci. Nutr. 2019, 4, 162-167.

46. Juárez, M.; Failla, S.; Ficco, A.; Peña, F.; Avilés, C.; Polvillo, O. Buffalo meatcomposition as affected by different cooking methods. Food Bioprod. Process. 2010, 88, 145-148. [CrossRef]

47. Mekonnen, M.F.; Desta, D.T.; Alemayehu, F.R.; Kelikay, G.N.; Daba, A.K. Evaluation of fatty acid-related nutritional quality indices in fried and raw nile tilapia, (Oreochromis Niloticus), fish muscles. Food Sci. Nutr. 2020, 8, 4814-4821. [CrossRef] [PubMed] 
48. Leung, K.S.; Galano, J.M.; Durand, T.; Lee, J.C.Y. Profiling of omega-polyunsaturated fatty acids and their oxidized products in salmon after different cooking methods. Antioxidants 2018, 7, 96. [CrossRef] [PubMed]

49. Deman, J.M. Principles of Food Chemistry, 3rd ed.; Aspen Publishers, Inc.: Gaithersburg, MD, USA, 1999; pp. 118-149.

50. Steiner-Asiedu, M.; Julsham, K.; Lie, Q. Effect of local processing methods (cooking, frying and smoking) on three fish species from Ghana. Food Chem. 1991, 40, 309-321. [CrossRef]

51. Ozden, O. Changes in amino acid and fatty acid composition during shelf-life of marinated fish. J. Sci. Food Agric. 2005, 85, 2015-2020. [CrossRef] 